\title{
O CORPO E O COLETIVO: ESPETÁCULO E LITURGIA MIDIATIZADA NOS DISCURSOS DE CRISTINA FERNÁNDEZ DE KIRCHNER (2008-2015)
}

\author{
Gastón Cingolani ${ }^{\mathrm{i}}$ \\ Mariano Fernándezii
}

Resumo: Partimos da hipótese de que, nos discursos políticos, a midiatização não é uma dimensão secundária, inócua: é uma condição constitutiva das condições de produção, circulação e reconhecimento no espaço público. Este trabalho é a extensão de uma série dedicada às estratégias da presidência de Cristina Fernández de Kirchner. Seu corte será transversal: os regimes de visibilidade são tão fundamentais quanto as operações que foram utilizadas, estabelecendo-se ou transformando-se ao longo do tempo, articulando-se com contingências da agenda social e política e com a dinâmica midiática (conflitos com os maiores grupos de mídia, conflito com o setor agrícola, celebrações do bicentenário, morte de Néstor Kirchner, reeleição, promoção de La Cámpora como a principal organização política do Kirchnerismo, etc.). A análise revisa os critérios analíticos à luz da hipótese de que as estratégias são um resultado coadaptivo: a midiatização impõe condições e os atores sociais produzem suas próprias formas de intervenção pública.

Palavras-chave: Discurso político. Mediatização. Coletivos. Corpos.

\begin{abstract}
We start from the hypothesis that, in political discourses, mediatization is not a secondary, innocuous dimension: it is a constitutive condition of the conditions of production, circulation and recognition in public space. This work is the extension of a series dedicated to the strategies of the presidency of Cristina Fernández de Kirchner. Its cut will be transversal: the visibility regimes are as fundamental as the operations that were used and, with it, establishing or transforming themselves over time, articulating with contingencies of the social and political agenda and with the media dynamics (conflicts with the major media groups, conflict with the agricultural sector, celebrations of the bicentennial, death of Néstor Kirchner, re-election, promotion of La Cámpora as the main political organization of Kirchnerism, etc.). The analysis reviews the analytical criteria in light of the hypothesis that strategies are a coadaptive result: mediation imposes conditions and social actors produce their own forms of public intervention.
\end{abstract}

Keywords: Political discourse. Mediatization. Collectives. Bodies.

\footnotetext{
' Docente do Instituto de Investigação e Experimentação em Arte e Crítica da Universidade Nacional das Artes (UNA), Argentina. E-mail: gastoncingolani@gmail.com.

ii Bolsista de Pós-doutorado do Conselho Nacional de Investigações Científicas e Tecnológicas (CONICET) no Instituto de Investigações em Humanidades e Ciências Sociais da Universidade Nacional de La Plata (IdHICS-UNLP). E-mail: marianofc81@gmail.com.
} 
EID\&A - Revista Eletrônica de Estudos Integrados em Discurso e Argumentação, Ilhéus, n. 16 esp. "Discurso e argumentação na política latino-americana, set.2018.

\section{Introdução}

O presente trabalho propõe-se a avançar na análise do discurso político além do tratamento de sua matéria linguística (como transcrição de alocuções). Se se assume que a noção de discurso designa a composição semiótica heterogênea dos produtos significantes (independentemente da complexidade dessa composição), então será necessário voltar a unir o que nós, analistas, geralmente separamos: reinserir a voz em um corpo, o corpo no cenário, o cenário em um espaço, o espaço em um tempo. O discurso político se mostra, então, em primeiro lugar, como variante de intervenção sobre o espaço público, e por isso, incrustado em uma dupla temporalidade: política e midiática.

É possível que essa afirmação seja válida para quase qualquer discurso político, especialmente para entender a centralidade e o magnetismo dos discursos de Cristina Fernández de Kirchner ao longo de seus dois mandatos como Presidenta da Argentina (2007-2011 e 2011-2015). Quase todos os seus discursos podem ser pensados como intervenções sobre o espaço público, e se inserem, como tais, em uma dupla temporalidade: política e midiática. Como intervenções, realizam uma divisão da temporalidade do sistema de mídias; são, neste ponto, táticas de midiatização. Quando são televisivas (prontas para serem midiatizadas), essas alocuções estão inseridas em regimes de visibilidade: dispositivos de encenação, organizados como situação de interação entre presentes, mas constitutivamente preparado para um terceiro, o "público". Enquanto regimes de visibilidade, são modos de encenar o lugar do corpo presidencial no jogo de forças sociais e institucionais que dinamizam o sistema político.

Corpo e coletivo: na construção de uma liderança política, um e outro não podem se dissociar. O líder é um corpo e é, ao mesmo tempo, a encarnação de uma identidade coletiva. Um e outro, corpo e coletivo, se apresentam como objetos observáveis, dotados de uma materialidade visual e sonora, nas ruas, nos estádios, em estúdios de TV, encenados, postos em uma relação determinada. O presente trabalho está dedicado ao estudo da singularidade de um corpo e da configuração de um coletivo político. 
EID\&A - Revista Eletrônica de Estudos Integrados em Discurso e Argumentação, Ilhéus, n. 16 esp. "Discurso e argumentação na política latino-americana, set.2018.

1. O show de Cristina: preparativos para a análise

Cristina ${ }^{1}$ despertou (e ainda desperta) no fio histórico da Argentina, uma série de surpresas. Não nos referimos às surpresas trivialmente políticas, aquelas que podem ser interpretadas como ameaças ou oportunidades na disputa cotidiana pelos espaços de poder institucional e parainstitucional. As surpresas, as arestas salientes de que trataremos, dizem respeito a um conjunto de situações, algumas incidentais, que deram forma, ao longo de oito anos de presidência, a uma estratégia política a partir de um aspecto discursivo.

Alguns esclarecimentos conceituais, antes de prosseguir: por discursivo não entenderemos só o que se produz mediante a matéria linguística, a palavra; ele abarca todos os elementos significantes que compõe a encenação, considerando tanto a expressão verbal, como sua materialização em sequências audiovisuais, seja para transmissão televisiva (ao vivo ou gravada), ou transmissão em vídeos enviados a plataformas de acesso na internet.

A construção do político não só não se contrapõe ao discursivo, mas também o inclui, ou mais ainda, o materializa. A unidade de análise serão peças audiovisuais que condensaram midiatizações da discursividade da figura presidencial em circunstâncias históricas diferentes ${ }^{2}$, nas quais intervém maior ou menor quantidade de fatores heterogêneos em sua materialização e constituição. É isso o que nos permitirá ver assentamentos e rupturas, já que vale também esclarecer - o sentido é um emergente diferencial: a discursividade é um conjunto de sentido que transcende as intenções, a racionalidade e a identificação com uma fonte única e homogênea, e se torna significante pelos moldes aos que recorre e sobre os quais exerce marcas diferenciais. O conjunto dos aspectos propriamente discursivos dessas peças é o que chamamos encenação (VERÓN, 2001), não obstante: a) os condicionantes da encenação podem ser ou não de caráter discursivo (por exemplo, leis que permitem ou impedem a emissão de algo), e b) a noção de encenação pode parecer a contra face do "real" ou "espontâneo"; contudo,

\footnotetext{
${ }^{1}$ Neste texto, faremos referência à ex Presidenta Cristina Fernández de Kirchner como "Cristina", não só no intuito de simplificar a escrita e a leitura, mas também para destacar um aspecto que acompanha essa denominação: sua individualidade, sua personalidade, sua proximidade, sua confiança. Outras denominações enfatizam as apelações de algumas mídias antagonistas, suas iniciais (CFK), o uso de seu sobrenome de casada (Cristina [Fernández] [de] Kirchner), à estranheza que beira seu anonimato (Cristina Fernández).

${ }^{2} \mathrm{O}$ universo excede este trabalho: durante seus dois períodos no cargo, Cristina produziu quase uma centena e meia de discursos em Cadeia Nacional, além de outras mensagens registradas audiovisualmente e emitidas por sinais de televisão ou enviadas a plataformas de redes sociais.
} 
EID\&A - Revista Eletrônica de Estudos Integrados em Discurso e Argumentação, Ilhéus, n. 16 esp. "Discurso e argumentação na política latino-americana, set.2018.

para a teoria da discursividade (VERÓN, 1988) e suas derivações, sempre há encenação, porque não há acesso ao "real" fora de uma dimensão significante $e^{3}$. Finalmente, a noção de estratégia não implica senão uma hipótese observacional sobre um conjunto de elementos distribuídos no tempo. Não pretende interpretar o que "na realidade se quis fazer", seja em sua dimensão intencional ou na de um alinhamento pré-estabelecido, mas indica um sentido de conjunto, já produzido, com suas invariantes e suas oscilações, em relação com um contexto de outros discursos e situações.

\section{Cristina é um corpo}

Cristina é um corpo. Um corpo aqui quer dizer duas coisas. Por um lado, remete a uma série de operações de sentido que são constitutivas de uma estratégia - indissoluvelmente - política e discursiva. Essa série compromete a tensão entre a corporalidade individual (onde ocorrem traços de singularidade absoluta, tanto os que se atribuem ao "natural” ou "biológico", "psicológico", como os que se delegam ao aprendido, os traços de personalidade, inclusive o cultural, porque também carrega com o que tem de gênero, de classe, de estilo) e a institucional (o corpo da presidência é um corpo submetido a outros condicionantes que o diferenciam sistematicamente do resto dos corpos cidadãos). ${ }^{4}$ Esta arquitetura de tensões se expressa em operações de sentido.

Como se não bastasse, Cristina é um corpo que se expôs. Poderia se pensar que o corpo é algo inevitável. Mas isso seria supor que não haveria senão uma maneira única de fazer intervir essa dimensão ou esse componente na discursividade política. Como sabemos, nada mais distante do que acontece e aconteceu na história. Em uma conjuntura na qual - forçando o contraste - os corpos (inclusive os cidadãos) se denotam como algoritmos, sem outra espessura além de uma fórmula ou uma estatística incorpórea (CHENEY-LIPPOLD, 2011; LUPTON, 2016), a figura governante de Cristina teve em seu corpo uma figuração nuclear para sua estratégia. Queremos colocar à prova esta hipótese.

Todo corpo governante, como bem o aponta o clássico trabalho de Kantorowicz (2012 [1957]), constrói-se sobre uma dualidade, entre o que se

\footnotetext{
3 “Puesta en escena es sinónimo de puesta en sentido" (VERÓN, 2001, p. 77)

${ }^{4}$ Verón sustenta que não é uma relação quantitativa (um corpo presidencial não seria "ni más digno, más inteligente ni más púdico" que o corpo do cidadão), talvez "sería, paradójicamente, mostrar en alguna parte que se pone en escena la dignidad, la inteligencia o el pudor" [...] "Asunto de enunciación: el cuerpo del presidente sería un meta-cuerpo" (VERÓN, 1987, p. 33).
} 
EID\&A - Revista Eletrônica de Estudos Integrados em Discurso e Argumentação, Ilhéus, n. 16 esp. "Discurso e argumentação na política latino-americana, set.2018.

manifesta e o que transcende, entre o perene e o perecível, entre o espírito e o material. Ao longo de sua história, sociedades europeias (e, em seguida, suas herdeiras), mantiveram a concepção cristã do homem carnal que atualiza uma divindade virtual; esta matriz deu lugar ao monarca por mandato celestial, e mais tarde foram o Estado, a República, a Constituição, o Povo (entre outros) que substituíram esse poder supremo, encarnado materialmente por reis, líderes, presidentes, primeiros ministros. A metáfora orgânica dos corpos não se limitou a sua condição material e perecível, estendeu-se também às divisões corpusculares (órgãos), às hierarquias (cabeça e membros), à direcionalidade (superior-inferior). É possível que a midiatização icônico-indicial (a voz propagada pelo rádio e a fonografia, a imagem registrada e emitida com a fotografia, o cinema e a televisão) tenha, ao mesmo tempo, modificado e reatualizado o esquema (TRAVERSA, 2014). $O$ corpo do corpo: nunca antes foi tão literal e ao mesmo tempo tão exposto o corpo em sua fragilidade e dimensão material. Mas não devemos, com isso, esquecer de que se trata tanto como antes de um componente em um esquema que o contém e pelo qual é expresso. Está claro, então, que esse esquema tem algo de metalepse (GENETTE, 2004), como o ator que, olhando a câmera, extravasa a personagem e nos recorda sua substância ficcional. ${ }^{5}$

Retornamos a Cristina. A construção de seu corpo presidencial, por um lado, teve de fazer-se sobre uma carência, já que a base protocolar prevê um presidente homem. $\mathrm{O}$ corpo do mandatário masculino tem um grau zero estabelecido pelo vestuário invariável (salvo as modulações de estilo, cor, corte, e inclusive, tamanho do próprio corpo) do terno, camisa branca e a gravata que é regulador do tom - dos tons: o tom do terno e, também, o da situação contextual -. Ao contrário, o corpo da presidenta não conta com uma estrutura prévia para se vestir. ${ }^{6}$ Vestido, tailleur, combinação de calça ou saia e casaco, são as opções genéricas. Cristina desponta sua presidência com um vestido branco, que assinala sua condição feminina, ${ }^{7}$ assim como seu esplendor e sua potência. Não absorve: irradia. É um corpo centrífugo. Esta oposição não é só de estilo, é também de gênero, no sentido agora de feminino: o homem de terno carrega em seu corpo a representação institucional que $o$ interpela e que o satura. Esta Cristina que assume a

\footnotetext{
${ }^{5}$ Daí a importância do complexo enunciativo para seu tratamento (METZ, 1991; VERÓN, 1987).

${ }^{6}$ Sobre os interrogantes e paradigmas do possível no corpo presidencial feminino, cf. Soto (2012).

${ }^{7} \mathrm{~A}$ contraposição com o terninho se pode ler como a adaptação do vestuário à mudança de gênero.
} 
EID\&A - Revista Eletrônica de Estudos Integrados em Discurso e Argumentação, Ilhéus, n. 16 esp. "Discurso e argumentação na política latino-americana, set.2018.

presidência, vem dizer que ela pode e que, apesar de saber "que talvez me custe mais porque sou mulher" [...] "vou fazê-lo como sempre fiz todas as coisas que empreendi em minha vida: com minhas convicções, com minhas ideias". Cachos suspensos, adequadamente selvagens, anunciam que seu corpo vai abrir caminho à base de personalidade. Personalidade da vestimenta, aqui, opõe-se à impessoalização da posse.

Sua $v_{0 z}^{8}$, também, nesse dia, deu as cartas da apresentação: sua oratória de legisladora se manteve sobre a mesa com tom debatedor e combatente (o auditório parlamentar, aqui, o fez de buffer), e se apoiou sobre uma espontaneidade irrigada pela não leitura (que adquire forma de improvisação) e a - ainda incipiente $-{ }^{9}$ interação com os presentes.

Durante a semana frenética de 25 de março a 1 de abril de 2008, aconteceram quatro discursos. A agenda desses dias se concentrou na disputa com os setores que recusaram as medidas de retenções sobre exportações agrícolas. Nessa semana, foram transmitidos pela televisão os discursos oficiais ( 25 e 31 de março) e dois acontecimentos em massa (organizados em seu apoio, no dia 27 no Parque Norte e na Plaza de Mayo, em $1^{\circ}$ de abril) com um impacto enorme em termos políticos. Nessa série de discursos, a figuração presidencial de Cristina consolidou sua forma. É difícil não ver que essa figuração foi proveniente de fatores diversos e, também, heterônomos. Em 25 de março, do Salón Sur da Casa Rosada, detrás de um cavalete, Cristina proferiu um discurso com um auditório que a escutava e a acompanhou com aplausos. Este último detalhe é a sustentação do direcionamento de seu olhar a esses copresentes. Diferentemente do que aconteceu por décadas na Argentina, quando os presidentes e ministros empregavam o dispositivo da Cadeia Nacional dirigindo-se a sós com o olhar fixo na câmera (e em todos os telespectadores ao mesmo tempo), o operador auditório em presença + nãoolhar-à-câmera + transmissão ao vivo não só se erigia como diferente, mas também como inabitual ou inadequado à figura presidencial nessa situação. Retomamos os três regimes audiovisuais da discursividade política que Cingolani (2015) chama "mediação", “contato” e “espetáculo”: o primeiro consiste na palavra da figura presidencial em diálogo com um jornalista ou

\footnotetext{
8 Sem fazer um desenvolvimento exaustivo, referimo-nos à dimensão da vocalidade e não oralidade, do modo como são tipificados por Meschonic e recuperados por Maingueneau (1999) os três polos: vocal, oral e escrito.

${ }^{9}$ Registramos este recurso já no lançamento de campanha como candidata a Senadora Nacional em 2005 no Teatro Argentino de La Plata (BARREIROS e CINGOLANI, 2007).
} 
EID\&A - Revista Eletrônica de Estudos Integrados em Discurso e Argumentação, Ilhéus, n. 16 esp. "Discurso e argumentação na política latino-americana, set.2018.

entrevistador mediador, o segundo se erige pelo olhar para a câmera para estabelecer contato direto pelo eixo do "olhos nos olhos" (VERÓN, 1983) e o terceiro discorre como una cena entre copresentes, onde o que faz às vezes de auditório mantém uma relação protética (BARREIROS, 2005) como nos shows. ${ }^{10}$ Dos três regimes, Cristina sustentou praticamente todos os seus discursos no modo show.

Ao mesmo tempo, lembremos que o uso da Cadeia Nacional é competência do Poder Executivo, segundo determinaram as duas leis que sucessivamente regularam o uso das radiofrequências e os canais televisivos durante os oito anos de governo de Cristina. ${ }^{11}$ Com este dispositivo, a figura presidencial pode não só falar a todos os telespectadores simultaneamente, interpelando-os em um mesmo gesto discursivo como cidadania, com uma mesma encenação que articula questões enunciativas, técnicas e legais. 0 caso inovador de Cristina é - desde antes de sua primeira mensagem em Cadeia Nacional, transmitida em 9 de junho de 2008 - que, para sua encenação apostou em interpelar de maneira direta ao seu auditório contíguo, e indiretamente aos telespectadores, não olhando em nenhum momento para a câmera. Esta disjunção gerou outras instâncias de apelação à cidadania, assim como também uma revalorização da figuração dos auditórios copresentes em seus atos e discursos, tal como já proposto (CINGOLANI, 2012) e se retoma neste mesmo trabalho.

Por outro lado, os canais de notícias tomaram a liberdade de retransmitir os discursos e intervir em sua organização audiovisual. O resultado das duas estratégias sobrepostas foi muito interessante e eloquente. Enquanto a Presidenta falava, construíam-se três destinações simultâneas, ainda que não equivalentes. A destinação imediata - o auditório copresente -, que estava composta (implicitamente, mas não tanto ${ }^{12}$ ) por representantes de setores

\footnotetext{
10 Apesar de Cingolani (2015) optar pela denominação "espetáculo" para esta modalidade, preferiremos a denominação de show para este regime de enunciação política audiovisual, a fim de não sobrepor as etiquetas (como a que empregam Dayan e Katz (1995)) e considerando que o discurso político sempre foi espetáculo. Por outra parte, é necessário que esclareçamos que nem show nem espetáculo têm para nós valor pejorativo, nem se opõem a algo que possa ser considerado mais "real" ou "verdadeiro" ou "espontâneo". Ao contrário, além de excelentes descritores de um modelo consagrado, são ontologicamente equivalentes a qualquer dos outros regimes (PETRIS, 2006; VERÓN, 1999; CARLÓN, 2004).

${ }^{11}$ A chamada "Ley de Radiodifusión" 22.285 foi sancionada em 1980, durante a ditadura militar, e reformada por decreto durante o governo de Menem; em 2009 se promulgou a "Ley de Servicios de Comunicación Audiovisual" 26.522.

${ }^{12}$ A figuração de um auditório que acompanha, rodeando e em frente à Presidenta, foi característica não só desde o primeiro discurso, como também desde seu lançamento em 2005 como candidata a senadora nacional. Sua construção articulou sua exibição visual, a presença
} 
EID\&A - Revista Eletrônica de Estudos Integrados em Discurso e Argumentação, Ilhéus, n. 16 esp. "Discurso e argumentação na política latino-americana, set.2018.

afins à dirigente, organizado pela estratégia presidencial; a destinação produto de sua transmissão, ou seja, os milhões de telespectadores que viram e escutaram esses discursos em suas telas em algum lugar; e como efeito da "tela dividida" (ou "tela na tela"), ordenado pelos canais que modificaram a imagem da transmissão original, apareceu uma terceira destinação, que na verbalização dos discursos políticos tem um lugar tipificado como o destinatário aludido (nem sempre explicitamente) em termos polêmicos ou antagônicos. De forma inédita, em outro segmento da tela, os canais de notícias colocam em destaque manifestantes do setor agropecuário que, naquele mesmo momento, a partir dos lugares em que ameaçavam bloquear as estradas, escutavam em seus rádios o discurso presidencial. O mais interessante disso é que o efeito de sentido se multiplicou em várias camadas: por uma parte, os canais de notícias deram visibilidade a setores que até então estavam emergindo como tais; habilitaram-se a si mesmos (esses meios) como espaço implícito de articulação discursiva dos setores opositores ao governo; e em terceiro nível, produziram uma cena dialógica onde o que havia era um discurso monologado: a palavra presidencial não tem, estatutariamente, interlocutor. Mas a copresença de indivíduos ou grupos do setor manifestante no outro espaço da mesma tela (inclusive, sua equivalência ou seu tamanho ampliado com a consequente inversão da relação figura-fundo), e as respostas gesticulares, ao vivo e simultaneamente, de desaprovação e de negativa frente ao pedido presidencial de suspender os bloqueios, deram lugar a uma encenação na qual o estatuto da palavra presidencial se viu afetado, de modo inédito, por estas contraposições. Está claro que as respostas a um discurso político - ao presidencial não menos que a outros - se fazem ouvir nas mídias

sonora (por exemplo, no discurso de 9 de junho de 2008, o locutor oficial anuncia o início da Cadeia Nacional enquanto o auditório canta sonoramente canções partidárias de apoio ao governo, e uma câmera toma desde o fundo essa cena, como entrada visível para o auditório) e a interpelação e interação da oradora com alguns dos presentes. Como se propunha em (CINGOLANI, 2012, p. 5960): "La puesta en escena televisiva se asemeja a una conferencia de prensa o a la transmisión informativa de un acto partidario [...] la configuración de esa oratoria con un auditorio en presencia, completa la escena, y la vuelve aún más "natural". Sin embargo, la transición de una estrategia canonizada hacia una innovación comporta riesgo; aquí señalamos dos grandes pérdidas. La principal es la ya mencionada ausencia de la operación específica de mediatización del contacto directo con el televidente a través de la mirada a cámara, adoptando en su lugar, la forma de una escena que se asemeja a la de la ficción: se trata de una situación en la que el vehículo de identificación es la entidad cuasi-viva que está inmersa en la escena. Frente a ello, el espectador sólo puede re-ingresar a la escena por vía de esa identificación compleja que ha descrito (METZ, 1979) para el cine de ficción, con alguno de los sujetos allí figurados (incluido allí el sujeto colectivo "auditorio", que funciona como prótesis o prolongación del espacio doméstico de expectación). En términos de la teoría peirceana, y para simplificar la idea, podríamos decir que se permuta un vínculo indicial por uno icónico, un pasaje del contacto a la identificación.” 
EID\&A - Revista Eletrônica de Estudos Integrados em Discurso e Argumentação, Ilhéus, n. 16 esp. "Discurso e argumentação na política latino-americana, set.2018.

em uma sequência quase imediata, mas necessariamente posterior. ${ }^{13}$ Nestes casos que mencionamos, a resposta não foi imediata mas simultânea e em um mesmo espaço midiático: a presidenta fazia um pedido num espaço físico, no mesmo momento os manifestantes lhe respondiam negativamente em outro espaço físico, e esse "diálogo" se produzia ao mesmo tempo em um espaço midiático para um terceiro, único observador do diálogo. Esta sobreposição de duas estratégias colocadas em cena se repetiu em vários dos discursos nessa conjuntura, como os de 27 e de 31 de março.

Cristina assumiu e sustentou esse modelo de show como dispositivo enunciativo para a midiatização de quase todos os seus discursos oficiais durante seu mandato como Presidenta, afirmando-o como sua estratégia audiovisual principal. Sustentará, uma vez mais, esta base enunciativa nos discursos em Cadeia Nacional, utilizada pela primeira vez em 9 de junho desse ano, ao celebrar os bombardeios na Plaza de Mayo. ${ }^{14} \mathrm{O}$ aspecto conjuntural da situação de disputa com um setor que se podia tornar visível (no sentido mais literal, o que nem sempre é factível) favoreceu um aspecto da contra estratégia das emissoras ante o discurso da Presidenta. Esta circunstância não se repetiu nos anos seguintes. Mas o episódio não foi menor nem inócuo: com o tempo, corroborou-se que as intervenções com imagens e títulos sobrepostos também ajudaram à modulação e modalização da palavra presidencial por parte das emissoras de notícias que retomavam a transmissão. Posteriormente, a Ley de Servicios de Comunicación Audiovisual (26.522) estabeleceu, em seu artigo 75 e sua regulamentação, duas restrições que contemplam diretamente situações como as descritas: obriga aos códigos jornalísticos a realizar a transmissão e lhes impede de alterá-la ou fazer alterações durante ela.

Em $1^{\circ}$ de abril e 18 de junho de $2008^{15}$, realizaram-se dois eventos em massa na Plaza de Mayo, promovidos como apoio a seu governo na complexa conjuntura política de tensão com o setor agropecuário. Única oradora nesses

\footnotetext{
${ }^{13}$ Hoje, os espaços públicos que se desdobram nas chamadas "redes sociais" promoveram outra simultaneidade midiatizada.

${ }^{14}$ Os meios não afins ao governo também vão sustentar o procedimento da tela dividida e os textos sobrepostos para opor-se à estratégia da encenação presidencial em sua retransmissão ao vivo, até que a nova lei restrinja esses recursos. Por outro lado, a estratégia da tela dividida e a sobreposição, assim como outros exercícios argumentativos, funcionaram de maneira regular como forma de edição posterior à transmissão em Cadeia Nacional, mesmo depois da lei 26.522.

${ }^{15}$ Vídeos de fragmentos desses discursos: (Acesso em: 10 ago.2017)

(01.04.2008) https://www.youtube.com/watch?v=ol4sem1G-Fo

(18.06.2008: https://www.youtube.com/watch?v=Bro_4RHesGo
} 
EID\&A - Revista Eletrônica de Estudos Integrados em Discurso e Argumentação, Ilhéus, n. 16 esp. "Discurso e argumentação na política latino-americana, set.2018.

acontecimentos, a voz de Cristina encarnou Eva Perón, tal como mostra Ramirez Gelbes (2012). Com maior nitidez no acontecimento de 18 de junho, extraiu uma voz "mais aguda que o habitual”, "enrouquecida", cuja visceralidade sustentava "uma gestualidade e um tom tensos, inflamados" (RAMÍREZ GELBES, 2012, p. 296). O eco sonoro da Eva oradora frente à massa foi realçado, por sua vez, pelo eco visual da transmissão televisiva, que emulou a figuração (TRAVERSA, 1997) dos indivíduos e da multidão na praça prestando seu apoio, tal como se pode ver nas cenas filmadas de manifestações durante o primeiro peronismo ${ }^{16}$. A imagem do abraço final com Néstor, imortalizado como emblema do kirchnerismo, também se apoiou na iconografia do peronismo original. Se durante os anos de governo kirchnerista, o uso de simbologia peronista ou justicialista possa ter sido reduzido $^{17}$, a voz, os corpos, as encenações, ao contrário, conferiram a principal substância à estilística de seus atos públicos. Com respeito à voz, Cristina não repetiu a figuração que evocava Eva. ${ }^{18}$ Futuramente, entretanto, produziu sua própria paleta de tons vocais, que - convém destacar - foi enunciativamente significativa e sensível aos contextos. Seus tons se ajustaram segundo dois grandes modos que seguem a lógica do entorno: um modo expansivo para os espaços abertos (praças, prédios abertos ao público) e outro um pouco mais atenuado para os espaços de encontro fechados (salões da Casa Rosada, recinto do Congresso, espaços delimitados, interiores). Esses dois modos ofereceram uma intensidade alta e uma médiaalta, respectivamente, contrastando com os de baixa intensidade nas poucas mensagens dirigidas na modalidade contato (cujo primeiro episódio se produzirá em $1^{\circ}$ de novembro de 2010). Esta adequação é significativa: embora se possa ver como "natural" que em uma mensagem dirigida a sós frente a uma câmera, o tom da voz não soe grandiloquente (em contraste com o entusiasmo dos eventos de massa, grandes e movimentados). Entretanto, na história argentina, há antecedentes memoráveis de outras estratégias, de Presidentes que falavam enfaticamente a sós frente à câmera e Ministros de

\footnotetext{
${ }^{16}$ Vídeos de fragmentos de discursos de Eva Perón e de suas transmissões nos quais se podem apreciar estas operações de figuração (Acesso em: 10 ago. 2017): do discurso de renúncia de Eva Perón (em agosto de 1951) https://www.youtube.com/watch?v=HF_RIoxKoxU ; do discurso no Día de la lealtad (17 de outubro de 1951 e primeira transmissão televisiva na Argentina) https://www.youtube.com/watch?v=cMrVm7j4nzU

${ }^{17}$ A efígie de Evita, surgindo por trás de Cristina (visível a partir do edifício do Ministério de Desarrolo Social) em numerosos discursos da casa de Gobierno, foi o emblema dessas exceções.

18 Contudo, a erótica performática de Cristina não está em nada desagregada da saga que configurou nitidamente a Eva Perón. Cf. (VALDETTARO, 2014, p. 138-139).
} 
EID\&A - Revista Eletrônica de Estudos Integrados em Discurso e Argumentação, Ilhéus, n. 16 esp. "Discurso e argumentação na política latino-americana, set.2018.

Economia que vociferavam em seus anúncios sobre as medidas e restrições dirigidas à nação. A performática dos tons de voz, reticente a ser codificada pela infinidade de matizes e variáveis, é mais bem referível a partir de sua função ilocutória por mecanismos indiciais; os tons se tornam reconhecíveis por recorrência e hábito, mas não por isso, esta performática é arbitrária e convencional. ${ }^{19}$

Mas há outro aspecto que é relevante na estratégia de discursos de Cristina e no sentido do uso tonal de sua voz. Houve duas variações reconhecíveis que modalizaram, de maneira relevante, uma grande proporção de seus discursos, variações que poderíamos chamar precária ou provisionalmente replicação e advertência. Apoiando-nos no dispositivo analítico do aspecto enunciativo do discurso político, de Verón (1987), a replicação consistiria em uma modalização de enunciados nutridos dos componentes descritivo e didático, ${ }^{20}$ nos quais se expõem e avaliam situações específicas ou "princípios gerais" respectivamente; de maneira análoga, a advertência reforça modalmente enunciados com um componente prescritivo acerca de um dever. Em que se diferencia a estratégia de Cristina? Qual é o valor agregado de uma dinâmica que não é alcançada pela classificação veroniana dos componentes enunciativos do discurso político? Sua voz manifesta uma ênfase cuja carga de antitética não se pode entender no marco de uma interpelação a seus ouvintes imediatos, copresentes, caracterizados por sua relação de afinidade e apoio. Vale dizer que constrói um co-enunciador (CULIOLI, 1990) ao que se contrapõe, com o qual polemiza. Articuladas com a estratégia modal que chamamos show, ambas as modalidades organizam enunciativamente uma tripla relação entre a figura enunciadora, o destinatário copresente (copartidários ou afins) e um terceiro, aludido. Esse terceiro aludido emerge como antagônico pela entonação - algumas vezes também reforçado no explícito - em defasagem com o encontro copresencial. E assim como as variações da intensidade (alto, médio-alto) são adequadas ao

\footnotetext{
${ }^{19}$ A caracterização de arbitrário e convencional dos ilocutórios se deve, em grande parte, aos postulados linguísticos de Austin (1982) e de Ducrot (DUCROT e TODOROV, 1995, p. 385). Aqui, estamos aplicando a noção de ilocutório à entonação vocal, o que é já uma adaptação e, por que não, um reforço da instância enunciativa. Boa parte das operações enunciativas são, precisamente, consuetudinárias, e portanto, não remetem a um código no sentido técnico do termo, que inclui o arbitrário e o convencional, mas a uma sedimentação que se reconhece como pertinente (ou não) produto de sua normalização, quer o hábito remeta a um esquema mais ou menos "individual", "grupal" ou "cultural", o que incluem fatores discursivos e extradiscursivos.

${ }^{20}$ Entendemos que a caracterização de Gindin (2017) sobre o ethos magistral se complementa bem com a compreensão do fenômeno show, já que não é só o componente didático e seus recursos argumentativos: é uma cena completa, com o co-enunciador encenado em espaço e voz/corpo.
} 
EID\&A - Revista Eletrônica de Estudos Integrados em Discurso e Argumentação, Ilhéus, n. 16 esp. "Discurso e argumentação na política latino-americana, set.2018.

enquadramento situacional do âmbito de declamação, fazendo parte e completando a encenação do ato político de seu discurso, a divergência entre o tom de advertência ou de replicação e a relação de proximidade emotiva e de concordância com seu auditório imediato adquire sentido como resposta a setores aos quais alude com seu tom enfático, marcando o dissenso e a contraposição.

\section{Entre o erótico e a morte: evolução do corpo presidencial}

Em 27 de outubro de 2010 falece seu marido e ex-presidente, Néstor Kirchner. Durante três dias se velou seu corpo na Casa Rosada, por onde circularam milhares de pessoas para prestar condolências também à presidenta e sua família. A transmissão televisiva desses funerais teve uma cobertura oficial e ininterrupta, replicada, por sua vez, por todos os canais abertos e de notícias a cabo. A figura de Cristina foi, sem dúvida, a mais importante. Seu corpo foi atração de olhares sobre como processava, como transmitia sua dor íntima em conjunção com sua exposição política. No espelho, outro corpo, o de seu marido, não visível, e falecido.

Quatro dias depois, Cristina fala em Cadeia Nacional, com uma modalidade totalmente diferente à que vinha empregando: o discurso sai gravado, ela está sozinha em seu escritório, olhando para a câmera. Conservando o luto que não deixará de maneira plena pelos dois anos seguintes, faz menção a seu "momento mais doloroso" (em réplica a aqueles que, diz ela, anunciaram que é seu momento "mais difícil”). A cena é densamente íntima, cheia de indícios: seu corpo satura a circunstância, a voz flui entristecida enquanto suas mãos se acariciam de desconsolo e comoção. Cada instante no fio de seu discurso parece o último antes da interrupção, que não se chega a produzir. Algumas semanas mais tarde, menos comovida, retoma este esquema, conservando em sua voz o tom próximo, íntimo, para anunciar a renegociação da dívida com o Club de París. Alude a seu momento pessoal muito sutilmente, sem palavras, só com uma pausa e um suspiro, para expressar, em seguida, que não vai deixar de lado suas responsabilidades “porque é minha obrigação como Presidenta de todos os argentinos". Estas duas mensagens confirmam e, ao mesmo tempo, desafiam a teoria dos dois corpos, tal como se concebe desde Kantorowicz. Se o corpo natural do rei fraqueja, o que se protegerá é o corpo mais importante, o corpo político, inclusive à custa daquele. Cristina põe o corpo natural, debilitado, como 
EID\&A - Revista Eletrônica de Estudos Integrados em Discurso e Argumentação, Ilhéus, n. 16 esp. "Discurso e argumentação na política latino-americana, set.2018.

modalizador do corpo político, como revelador ou performador de uma fortaleza política. Este encontro entre as duas dimensões ficará mais desprotegido como parte da estratégia discursiva presidencial. Embora diluída entre outros signos - o estivesse desde o começo, esta circunstância extrema a fará evidente e a consolidará.

Por quase todo o resto de sua permanência no cargo, Cristina voltou em suas apresentações públicas à modalidade show. Seu corpo, sem abandonar o simbólico negro de luto, modalizou suas apresentações com as variações de vestuário (SOTO, 2012). O caso mais relevante, certamente, foi o de seu aparecimento vestindo calças ou leggings numa inauguração em Ezeiza, em setembro de 2013. O detalhe - que trouxe comoção jornalística nas redes sublinha outra dimensão que, em sua estratégia, desde o início, Cristina também modalizou em corpo e verbo: a condição do gênero. ${ }^{21}$

O gesto - ainda que ocasional - foi taxado de excessivo: suficiente para ser eficaz. Cristina lançou mão de numerosos gestos de feminilidade incrustada em um cargo historicamente masculino ou masculinizado, problemática que arduamente também atravessaram primeiras chefes de Estado como Dilma Rousseff e Michelle Bachelet na América Latina, ou Angela Merkel e Margaret Thatcher na Europa, assim como candidatas francesas ou norte-americanas que não chegaram a ocupar o cargo (COULOMB-GULLY, 2012; SOTO, 2012; FRANÇA e GUIMARÃES CORRÊA, 2012; BASTIAN TRAMONTINI, 2014; PANKE e IASULAITIS, 2016; VITALE, 2016). Talvez Cristina tenha encarnado a erótica feminina do poder em uma performática inédita na história argentina, e bastante incomum em outros países (VALDETTARO, 2014). ${ }^{22}$

Em 8 de outubro desse ano, Cristina se submeteu a uma cirurgia que a manteve fora do cargo e em repouso por quarenta dias. Em 18 de novembro, ela reapareceu em público, escolhendo uma modalidade também excepcional e inovadora. Não utilizou o meio televisivo, mas carregou em sua conta de Twitter um vídeo filmado por sua filha, Florencia. Os marcadores enunciativos que enquadram esta modalidade estão espalhados no começo do vídeo, no

\footnotetext{
${ }^{21}$ Inclusive o suplemento Entremujeres do jornal Clarín (o meio mais crítico ao seu governo) trouxe como título, em legenda questionadora dos discursos questionadores, "Las calzas de Cristina... ¿Por qué no?” ao que indagava no sobretítulo: “¿Una cuestión de género?” 27/09/2013 - 13:40 hs https://www.clarin.com/genero/calzas-cristina-kirchner-moda-prejuiciosgenero_o_HJPra6FwXx.html (Acesso em: 9 ago.2017)

${ }^{22}$ O trabalho de Valdettaro (2014) é excepcional em seu aprofundamento sobre este aspecto da performática de CFK.
} 
EID\&A - Revista Eletrônica de Estudos Integrados em Discurso e Argumentação, Ilhéus, n. 16 esp. "Discurso e argumentação na política latino-americana, set.2018.

qual se dá um duplo jogo com o dispositivo do olhar. Cristina, olhando de frente para a câmera, pergunta: “Florencia, podemos começar?". Mas a imagem é a do visor da tela, com um grande painel negro e indicadores gráficos: é a imagem de uma imagem de Cristina. De imediato, outra imagem (outra câmera), levemente lateralizada e sem painel, enquadra-a dizendo "Agora sim? Bom. Olá". A montagem volta à primeira tela à qual ela aponta e pergunta: “É esta câmera que tenho que olhar ou a sua?", e aponta fora do enquadramento. Finalmente, retorna à segunda imagem, aquela oblíqua, que será a definitiva, e voltará a saudar: "Olá. Depois de tantos dias estamos de volta em contato. Florencia está atrás da câmera, está me filmando...". A rede social, a dupla câmera que marca que alguém filma, junto a sua indicação física e verbal, a obliquidade, encaixa com o contexto caseiro a partir do qual falará durante 6 minutos e 54 segundos, sairá do enquadramento e voltará a entrar, se cruzará frente à câmera e terminará com o encerramento - abrupto - do vídeo. Esse reingresso ao espaço público mostrou um corpo sem rastros de doença nem convalescência, acentuado por uma modalização que tirou do meio também todo o rastro protocolar. Se já era uma característica discursiva de sua estratégia evitar a modalidade que chamamos mediação (não a entrevistas, não a coletivas de imprensa, não a visitas a programas de televisão), e sua oratória acentuava a liberação dos modismos protocolares, neste vídeo se aposta modalmente em uma enunciação duplamente desintermediada: um tipo de corpo natural (no sentido de contraposto ao corpo político) em estado natural: sem meios nem institucionalidade.

A aposta foi diferente em sua mensagem de 26 de janeiro de 2015. A poucos dias da morte do fiscal Nisman, apresenta em Cadeia Nacional o envio de um projeto ao Congresso para a criação da Agência Federal de Inteligência. A cena inverteu os polos: a primeira imagem é um plano geral que toma de frente a Presidenta, sentada em uma cadeira de rodas, com um pé engessado. Olhando para a câmera, começou dizendo: "Bom, boa tarde a todos e a todas. Este é um lugar, uma posição, um tanto incomum para me comunicar com vocês, mas contingências de saúde e prescrições médicas me obrigam a fazêlo desta maneira". A câmera se aproxima lentamente, e mantém um plano americano até o final. Vestida completamente de branco, deu um discurso cujo tom foi tenso durante os 58 minutos e meio que durou. O discurso, nitidamente, foi resposta a um contexto de adversidade, seu corpo o expressou mostrando o limite do próprio corpo, em estado, posição e vestimenta. A imagem não dissimulou essa tensão (a cadeira de rodas poderia 
EID\&A - Revista Eletrônica de Estudos Integrados em Discurso e Argumentação, Ilhéus, n. 16 esp. "Discurso e argumentação na política latino-americana, set.2018.

não ter sido exibida), mas sim sua encenação, uma encenação no limite, em contato pleno com a câmera.

\section{O espetáculo dos coletivos: cerimônias e liturgias}

Estado e espetáculo, escreveu Régis Debray (2000 [1993], p. 63), são termos redundantes. "Um estado que não desse nada a ver ou a escutar, sem rituais, monumentos e documentos, seria pior que um rei sem diversões: nada. O que explica a frivolidade das denúncias em voga do "Estado espetáculo". São as modalidades do "espetáculo" as únicas que fazem época e sentido". Nos perguntamos agora pelo tipo de espetáculo que pode definir uma época. Porque o kirchnerismo foi, também, a configuração de um espetáculo político. Ele mesmo se ofereceu como tal, da maneira e no lugar - o único, talvez? - em que esse espetáculo pode realizar-se de forma perfeita: como congregação coletiva televisada, ao vivo. Esses espetáculos foram menos peças de comunicação eleitoral que encarnações dramatizadas das formas de legitimidade que podem fundamentar uma liderança e uma identidade política. Desse tipo de espetáculo de autocelebração política - de configuração de um coletivo - queremos falar agora.

Para isso, vamos comparar dois tipos de atos políticos, dois modos de intervenção sobre o espaço público midiatizado que, conforme foi avançando o segundo governo de Cristina, tenderam a sobrepor-se até dar forma a uma verdadeira liturgia política.

O primeiro tipo de ato corresponde à irrupção do espetáculo televisado de investimento público da juventude kirchnerista como sujeito político ao que Cristina atribui, sobretudo a partir de 2010 e com mais força depois da morte de Néstor Kirchner, o papel protagonista de encarnar a continuidade do "projeto" e que se atribui a si mesma a tarefa de cuidar e proteger seu líder. Para ordenar a exposição, escolhemos uma série de quatro atos que estudaremos a partir de seus registros audiovisuais: o primeiro é o ato de 14 de setembro de 2010 no Luna Park; o segundo é o ato realizado no Club Atlético Huracán, em 11 de março de 2011, em comemoração ao aniversário da vitória do justicialismo nas eleições presidenciais de 1973; o terceiro é um ato no estádio do Club Vélez Sarsfield, em 27 de abril de 2012; e o último desta série é o primeiro "pátio militante", de 20 de novembro de 2013. 
EID\&A - Revista Eletrônica de Estudos Integrados em Discurso e Argumentação, Ilhéus, n. 16 esp. "Discurso e argumentação na política latino-americana, set.2018.

A segunda série corresponde à celebração de 25 de maio. Data fundacional da história argentina, 25 de maio foi, por sua vez, o dia escolhido por Néstor Kirchner, em 2003, para assumir como Presidente da Nação. Essa sobreposição entre uma celebração pátria e a tomada de posse do cargo presidencial foi-se convertendo, especialmente, a partir do falecimento de Néstor Kirchner em 2010, em um signo de transcendência histórica, pois facilitou a identificação de um marco da história nacional para ligar dois relatos fundadores: o da Pátria e o de renascimento do "projeto" kirchnerista, depois da profunda crise que se instalou em dezembro do ano 2001 na Argentina. Progressivamente, a celebração da declaração da independência data ritual do calendário cívico argentino - foi se transformando em autocelebração do kirchnerismo como projeto nacional e popular. Como consequência, no decorrer dos anos foi-se acentuando uma tensão entre a invocação a uma totalidade social e sua efetiva encarnação em um coletivo de fronteiras identitárias necessariamente diferenciadas e excludentes. ${ }^{23}$ Se esta tensão pode resultar em objeto de análise interessante é porque se expôs, precisamente, em uma instância institucionalmente orientada a repor, ainda que não seja mais circunstancialmente, um momento de comunidade plena. Neste caso, tomaremos como referência outros quatro atos, televisados pela Cadeia Nacional: o de 2012 (celebrado em Bariloche, província de Río Negro), e os de 2013, 2014 e 2015, realizados na Plaza de Mayo. ${ }^{24}$

Embora, como vemos, a sequência de atos pode ordenar-se em momentos (com seus dias, suas datas, seus lugares), o que nos interessa é reconstruir dois aspectos que, em nosso entendimento, terminaram por ser traços distintivos e, ao menos até dezembro de 2015, consubstanciais à identidade política do kirchnerismo.

O primeiro aspecto é a consolidação de um regime de visibilidade (LANDOWSKY, 1985) que chamamos cerimônia partidária e que funciona como o momento mais pleno de representação de uma comunidade militante com

\footnotetext{
${ }^{23}$ Essa tensão entre a singularidade de uma identidade e a universalidade da invocação à nacionalidade, tensão dramática na história política nacional, remete também ao peronismo clássico. Analisando o lugar que a Plaza de Mayo ocupou nas manifestações coletivas durante os governos de Juan Domingo Perón, Sigal (2006) acrescenta que "a esta significação [se refere à relação privilegiada da Plaza com a Pátria] o peronismo articulou a sua em uma combinação instável de totalidade e parcialidade social" Algo similar sustentou Plotkin (1995) em sua reconstrução de 17 de outubro como data fundacional do peronismo: "Gradualmente, 17 de outubro perdeu seu caráter comemorativo para se converter em rituais nos quais se recriava a comunhão simbólica entre o líder e o povo peronista".

${ }^{24}$ Todos os vídeos foram obtidos a partir do canal oficial do Youtube da Casa Rosada em setembro de 2016.
} 
EID\&A - Revista Eletrônica de Estudos Integrados em Discurso e Argumentação, Ilhéus, n. 16 esp. "Discurso e argumentação na política latino-americana, set.2018.

um líder. Deste tipo de acontecimentos midiáticos, o kirchnerismo oferece muitos exemplos; por isso, não é o tipo de regime de visibilidade em si mesmo o que merece atenção, mas sim sua progressiva incorporação a outro tipo de cerimônias - também televisadas e em Cadeia Nacional - nas que a liturgia política se converte em autocelebração de um coletivo.

O segundo se vincula com a dimensão narrativa - propriamente linguística - do discurso político. Uma estrutura argumentativa que, como bem explicou Eliseo Verón, é uma condição necessária para construir "coletivos identitários de longo prazo" (VERÓN, 1998). Poderíamos dizer: este segundo aspecto é a configuração de um relato e, ainda mais, do Relato, concebido em seu duplo registro de estratégia narrativa e de objeto de e em disputa.

\section{Os herdeiros: investimento e designação da juventude kirchnerista}

"Quem está na televisão e quer escutar a presidenta, desligue o televisor, porque só vai escutar uma militante peronista", diz Cristina em um breve fragmento de seu discurso diante da Juventud Peronista, reunida no Luna Park em 14 de setembro de 2010. Atrás dela, um palco repleto de militantes dessa juventude, instalada em um púlpito em cuja fachada se via pendurada uma bandeira do "Nestornauta", e acompanhada, em uma mesa situada ao lado, pelo próprio Néstor Kirchner, recém recuperado de uma intervenção cirúrgica, Cristina oferece um discurso programático ("Precisamos voltar a criar utopias, objetivos de vida, ajuda ao próximo, que nos levem a saber que não há destinos pessoais nem individuais") frente a uma multidão que grita, que canta ("Cristina, Cristina, Cristina coração, aqui estão os jovens para a liberação"), que pula e à qual ela batiza: " vocês são a Juventude Peronista do Bicentenário"

O ato é uma típica cerimônia partidária, um regime de visibilidade que se define porque encena a liderança como capacidade de condução de uma força política e o pertencimento a uma identidade delimitada, singular, de partido. Assim como as mobilizações cerimoniais, as cerimônias partidárias, organizadas pelo partido do Governo, deveriam caracterizar-se por sua excepcionalidade: não podem converter-se em rotina, mas também não podem submeter-se ao calendário ritual. São intercalações táticas: inserem-se na circulação pública de discursos para cristalizar um cenário político. Por isso, ao menos na sequência que estamos revisando, funcionam como atos parainstitucionais, realizados em lugares fechados da topografia urbana. $O$ espaço 
EID\&A - Revista Eletrônica de Estudos Integrados em Discurso e Argumentação, Ilhéus, n. 16 esp. "Discurso e argumentação na política latino-americana, set.2018.

fechado, a proximidade do auditório, a lógica da distribuição topográfica de lugares, habilita a conformação de uma espécie de circuito fechado, que se confirma na proxêmica sob a forma de gestos cúmplices, evidentes, breves peças dialogais com vozes que chegam a partir do público ${ }^{25}$. Mas não há circuitos fechados quando há transmissão televisiva. Curioso pedido o de Cristina, então, porque finalmente o ato está sendo televisado e, ali, ela não é "só uma militante a mais". E não o é porque não pode deixar de ser Presidenta, porque só nessa condição pode aspirar a realocar-se como uma a mais. E essa dissociação, que Cristina talvez tenha podido fazer porque, de fato, sempre foi uma militante, deve poder fazê-la, também, o espectador, inclusive uma vez desligado o televisor. ${ }^{26}$

Uma cena similar se produz - ou melhor: é produzida - no ato de 11 de março de 2011 no estádio do Club Huracán em memória do $38^{\circ}$ aniversário do triunfo de Héctor Cámpora nas eleições presidenciais de 1973. O estádio está repleto, as câmeras oferecem planos gerais, giram sobre a multidão embandeirada e ruidosa. O discurso audiovisual, sincronizado e atento aos vaivéns e aos picos dramáticos da alocução presidencial, reforça e habilita uma operação de identificação referencial (essas multidões, esses corpos agrupados que não podem individualizar-se, são um coletivo unificado), mas que requer do trabalho de organização simbólica que provê o discurso de Cristina para realizar uma operação de leitura simbólica: não são apenas multidões, são "a geração do bicentenário", "a juventude do campo nacional e popular", que "se está incorporando à política não contra alguém, mas sim, por alguém: pelos argentinos, para seguir melhorando as coisas". E, frente a essa juventude, Cristina se apresenta: "quero lhes dizer que esta tarde, em Huracán, não está a presidenta da república, mas a companheira de todos vocês e como companheira quero pedir a todas e a todos que este ato deste 11 de março seja em memória e homenagem a quem foi meu companheiro em toda a vida".

Esse gesto de abertura, convertido em ritual, repete-se no ato de 27 de abril de 2012 no estádio do clube Vélez Sarsfield: “Companheiras,

\footnotetext{
${ }^{25}$ Por exemplo, em uma passagem de sua alocução se escuta alguém gritar-Ihe "Aguente, Cristina", e ela interrompe o fio do discurso: "Claro que vamos aguentar, se te parece que não aguentamos, aguentamos o que eu creio que ninguém já aguentou". Nesse momento, as câmeras tomam uma imagem de Néstor Kirchner saudando ao público fazendo o "V" com os dedos.

${ }^{26}$ Esta cena é o oposto complementar dos discursos - que repassamos na primeira parte - da que Cristina fala como Presidenta em Cadeia Nacional sob a operação enunciativa de dirigir-se com seu olhar a seu auditório copresente: apesar de falar como mandatária de todos os cidadãos, seu discurso foge como cerimônia partidária.
} 
EID\&A - Revista Eletrônica de Estudos Integrados em Discurso e Argumentação, Ilhéus, n. 16 esp. "Discurso e argumentação na política latino-americana, set.2018.

companheiros, o primeiro é o primeiro: como presidenta, mas principalmente como militante, quero agradecer a todos vocês esta verdadeira festa de júbilo, de alegria e de nacionalidade". A data do ato é importante: a própria Cristina explica que havia sido pensado para 11 de março, mas que ela sugeriu realizá-lo em 27 de abril, data da eleição que em 2003 colocou Néstor Kirchner em posição de competir em segundo turno para alcançar a presidência da Nação. Data histórica, diz Cristina, "quando começamos nós mesmos a construir a partir de nossas convicções históricas, de nossos princípios políticos, uma história que estamos escrevendo nós mesmos e que jamais permitiremos que a voltem a escrever de fora".

Este ato já é uma liturgia política (RIVIÈRE, 1989): não só supõe uma exaltação coletiva e o reforço de uma ordem, mas sim a exposição de uma carga afetiva e uma intensidade emocional que aponta para a revitalização do coletivo político (RIVIÈRE, 2005). A transmissão televisiva acompanha e modaliza essa intensidade: a câmera em rotação sobre as agrupações, que podem distinguir-se por suas bandeiras, mas também, diferentemente do ato em Huracán, aproxima-se, com tomadas grupais, de conjuntos de pessoas que cantam, agitam os braços e se abraçam. O discurso audiovisual limita as generalizações: esses rostos não são necessariamente "jovens", ainda que sejam militantes. É o discurso de Cristina que recorta e abstrai, e opera o ato de unção: "quero dizer aos jovens, a esses que agitam as bandeiras do Che, de Tupac Amaru, de Evita, que vocês são a geração do Bicentenário", e mais ainda: "sinto que os verdadeiros guardiões deste legado são vocês, que não vão permitir jamais dar um passo atrás em tudo isso que conseguimos".

Considerados em relação a esses atos, os chamados "pátios militantes"27 resultam como uma continuação de um regime de visibilidade que o kirchnerismo já havia consolidado como espetáculo público televisado. Concebidos como variantes da cerimônia partidária, sua novidade se sustenta em dois traços que, mesmo evidentes, não devem deixar de ser assinalados: em primeiro lugar, o cenário, que já não será um estádio alugado, mas a própria Casa de Gobierno: ali, Cristina não poderá, então, pedir que se deixe de considerá-la Presidenta; em segundo lugar, o espetáculo da congregação

\footnotetext{
${ }^{27}$ Os patios militantes foram uma instância de encontro entre Cristina e a juventude kirchnerista nos pátios da Casa de Gobierno, e se realizavam geralmente depois de alguns atos públicos. O primeiro deles ocorreu em 20 de novembro de 2013. Usualmente, funcionavam da seguinte maneira: uma vez finalizado o ato, a juventude entrava na Casa Rosada e ali Cristina lhes falava da sacada de um dos pátios internos. O interessante, o memorável, é que se tratava de atos televisados, de modo que, novamente, eram - de fato- uma exibição da identidade kirchnerista.
} 
EID\&A - Revista Eletrônica de Estudos Integrados em Discurso e Argumentação, Ilhéus, n. 16 esp. "Discurso e argumentação na política latino-americana, set.2018.

do coletivo com seu líder se encerra sobre a relação, quase íntima, entre Cristina (Presidenta, militante) e a juventude kirchnerista.

\section{25 de Maio: da mobilização cerimonial à cerimônia partidária}

Contrastada com as celebrações de 25 de Maio dos governos precedentes (ao menos desde o retorno da democracia, em 1983) a comemoração kirchnerista introduziu um elemento diferencial: agregou ao protocolo institucional (com suas formas rituais cristalizadas ${ }^{28}$ ) o elemento da mobilização popular. ${ }^{29}$ Por essa razão, não pode pensá-las só como peças de comunicação política - não, ao menos, se se reduz esse conceito a produtos comunicacionais elaborados segundo uma estratégia publicitária.

Desde essa perspectiva, o momento inaugural desta forma litúrgica foi em 25 de maio de 2006 quando a confluência das organizações sociais como base social do governo se expõe na chamada "Plaza del Sí", na qual a "Frente para la Victoria' celebrou seu terceiro ano no poder, e que para Montero e Vincent (2013) marca o início do "kirchnerismo puro". O decurso dos anos mostrará que os critérios de "pureza" variarão; entretanto, aquele ato de 2006 expôs uma característica estável do kirchnerismo: a tendência a mostrarse publicamente por meio do que Novaro denomina "identidades por encenação", como modalidade de exibição da relação entre os "eleitores" e os eleitos, que, como tal, é diretamente tributária de sua manifestação no espaço público (NOVARO, 2011). A passagem que vai desde 2008 a 2015 mostra o progressivo deslocamento da identidade dos coletivos que participam dessa ação movimentista: não se transforma a "matriz" (revelada

\footnotetext{
${ }^{28}$ Em um de seus estudos sobre o tema, Amati (2010) recorda que: "O governo de Néstor Kirchner modificou o lugar de realização dos atos de maio rompendo com uma tradição que vem desde 1811. Ainda que essa tradição política e cultural tenha sofrido modificações desde a data do acontecimento que comemora tanto na estrutura do rito como na participação social, como veremos na seguinte seção, a continuidade estava marcada pela data e pelo espaço de realização: a praça e as instituições vizinhas (Casa Rosada e Catedral Metropolitana. Pela primeira vez, em 2005, o rito oficial de maio se realizou em Santiago del Estero; em 2007, em Mendoza; em 2008, em Salta e em 2009, em Misiones. Esta mudança - que não incluiu modificações na estrutura ritual - se realizou sob o argumento do federalismo e contra a centralidade de Buenos Aires".

${ }^{29}$ Como bem mostraram os estudos de Natalucci (2012; 2014) e Natalucci e Pérez (2010; 2014), a "matriz movimentista" foi introduzida pelas organizações sociais às quais a Frente para la Victoria integrou à denominada Frente Transversal como contrapeso do Partido Justicialista no período 2003-2006. Entre essas organizações, as mais importantes - Movimiento Evita e Movimiento Barrios de Pie - provinham do espaço militante de organizações sociais que lideraram a oposição não partidária ao neoliberalismo na década de 1990. Sua incorporação como aliados a um Governo Nacional implicou, assim, uma novidade.
} 
EID\&A - Revista Eletrônica de Estudos Integrados em Discurso e Argumentação, Ilhéus, n. 16 esp. "Discurso e argumentação na política latino-americana, set.2018.

pelo "regime de visibilidade"), mas sim o sujeito que a protagoniza: uma "juventude" que também, como pudemos ver, é "kirchnerista".

Iremos nos deter em alguns traços singulares das celebrações de 25 de maio entre os anos 2013 e 2015. O recorte se justifica por duas razões: em primeiro lugar, porque os atos se realizaram, depois de muito tempo, com a Plaza de Mayo como cenário, após vários anos nos quais o governo deslocou a celebração a outras províncias. Em segundo lugar, porque nestes anos se produz um movimento de incorporação do regime de visibilidade típico da cerimônia partidária a uma celebração cuja função é invocar uma forma de comunidade nacional. Esse formato da cerimônia partidária é o que, progressivamente, irá incorporando-se aos atos comemorativos de 25 de maio, em especial, a partir de 2013, à medida que o kirchnerismo vai se definindo, cada vez com mais clareza, como um movimento dinamizado pela (mas não por isso redutível a) relação direta e privilegiada entre Cristina e "os jovens", “os soldados de Cristina”. A seguir, sintetizamos, em alguns pontos, os traços mais notórios deste processo.

Em primeiro lugar, a transmissão televisiva permite observar a delimitação de uma força política, que se exibe na encenação cada vez mais ordenada dos atos, que se aperfeiçoam enquanto espetáculos; aperfeiçoamento técnico e cênico, e delimitação cada vez mais clara de seu espectador modelo, de seu sujeito, de um interpretante do kirchnerismo da era Cristina, a juventude. É Cristina quem, cada vez com mais insistência, vai produzir essa especificação, porque basicamente elege essa juventude politicamente organizada como interlocutora direta: são os que estão aí, frente a ela ("Quero lembrar e vejo em todos vocês, nessas caras jovens, as caras de outros jovens, de French, de Beruti, de Moreno, de Monteagudo os verdadeiros cérebros dessa revolução"), e com quem ela fala:

Por isso, quando naquele 2 de abril, lá no Sul, na Patagônia lembrando Malvinas eu disse "a Pátria é o outro", não estava pensando em uma frase ou em um slogan; a tragédia que depois ocorreu viu esta juventude incrível que se incorporava à política, voltar-se ao trabalho solidário para ajudar a esses que haviam sofrido a tragédia. E vê-los hoje alçando suas bandeiras quando vêm aos atos; quando os vejo hoje nos bairros junto ao Exército Argentino ajudando aos que menos têm cavando canais; quando os vejo hoje investigando nas universidades e nos laboratórios porque voltamos a ter universidade, recursos para poder fazê-lo; quando os vejo hoje nas novas universidades e com as novas possibilidades, sinto realmente que se cumpriu uma parte importante da tarefa. (25/05/2013) 
EID\&A - Revista Eletrônica de Estudos Integrados em Discurso e Argumentação, Ilhéus, n. 16 esp. "Discurso e argumentação na política latino-americana, set.2018.

Em segundo lugar, manifesta-se a composição cada vez mais delimitada da identidade dos coletivos que participam dessa liturgia. Mantém-se, então, o grau zero desse regime de visibilidade, instaurado em 2006, definido pela forma movimentista, mas os protagonistas já não são as organizações sociais pertencentes ao que Natalucci (2012) chama "espacio organizacional militante", mas sim, uma "juventude" que também é "kirchnerista" e que assume como tarefa política a proteção de seu líder: "Cara, gorila, cara, gorila, não vamos mais te avisar, se tocam em Cristina, que confusão vai se armar".

Dissemos que esses atos, além de exibir esse deslocamento no regime de visibilidade, vão aperfeiçoando-se como espetáculos. Como já o destacou Valdettaro (2014), vão se adequando, vão adotando uma forma performática: os atos abrem e encerram musicalizados com canções populares ("No me arrepiento de este amor", de Gilda o "La ciudad de la furia”, de Soda Stéreo), o cenário inclui uma passarela pela qual Cristina caminhará, como se estivesse adentrando-se na multidão, para saudar, uma vez finalizado seu discurso; também se acrescenta um mapping projetado sobre a Casa Rosada ou o Cabildo e um show de fogos de artifício como momento ápice. Por sua vez, aperfeiçoa-se o jogo de câmeras e planos da transmissão televisiva, em particular o uso recorrente de giros dinâmicos (com movimentos em plongée e contraplongée, e de ida e volta) que sobrevoam a multidão.

Essa mesma especialização da linguagem audiovisual permite a figuração mais acabada do coletivo que acompanha Cristina nesses lugares. A operação de atribuição simbólica - argumental - que consiste na construção de um prodestinatário que é uma juventude militante, ${ }^{30}$ complementa-se com as operações de figuração e de identificação referencial que a própria televisão facilita e produz. Quase como uma fatalidade, a incorporação do povo, sua encarnação atualizada e não sua evocação discursiva, é um recorte, uma exclusão. E a midiatização televisada acentua este fenômeno: ao trabalhar sobre a indicialidade, sobre a exibição e a identificação, faz com que a dimensão propriamente simbólica (terceiridade) que permitiria conceber o povo como um coletivo que se superpõe perfeitamente com os habitantes da nação, enfraqueça-se, porque a televisão a torna impossível ao expor os

\footnotetext{
${ }^{30}$ É importante esclarecer que a reivindicação da figura da juventude militante é um traço que caracteriza o discurso kirchnerista desde suas origens, como estudou Montero (2012), com precisão e lucidez, em sua análise dos discursos de Néstor Kirchner, entre 2003 e 2007: “Los militantes son retratados como jóvenes idealistas y soñadores, como activistas comprometidos con su causa, como hombres y mujeres 'comunes', que eran 'parte del pueblo' y cuya práctica política se fundaba en la fraternidad, el júbilo y la alegría compartida” (Montero, 2012)
} 
EID\&A - Revista Eletrônica de Estudos Integrados em Discurso e Argumentação, Ilhéus, n. 16 esp. "Discurso e argumentação na política latino-americana, set.2018.

indicadores de pertencimento partidário. Esse povo encarnado na multidão que enche a praça é uma totalidade excludente. ${ }^{31}$

Há, finalmente, três tópicos que ordenarão, como eixos ou ancoragens narrativos (PATROUILLEAU, 2010), ${ }^{32}$ a estrutura das alocuções nesses três atos cujo regime de visibilidade predominante é a cerimônia partidária. Em primeiro lugar, a reformulação plena do relato fundacional, que já não repousa em um coletivo (tal como até 2010) mas em Néstor Kirchner, convertido postmortem em uma figura providencial:

Neste novo aniversário de nossa querida pátria, quero confessar a todos vocês que nem ontem nem hoje têm sido dias fáceis para quem lhes fala. Junto a minha condição de argentina, como o resto dos 40 milhões que lembram e festejam sua pátria, surgem em mim também outras imagens, outras lembranças, porque faz exatamente 10 anos que meu companheiro de vida e de militância [...], o presidente - que paradoxo - menos votado de todos os processos democráticos [...] veio a encabeçar o processo de transformação e mudança mais importante das últimas décadas". (25/05/2013)

E proponho então a necessidade de que esta geração do século XXI, que deixou para trás um mundo que não existe nem política nem geopoliticamente, a necessidade de elaborar a partir de nossas próprias experiências como país, reelaborar todo esse pensamento de século XX e retomar como geração a necessidade de formular um projeto de país que tem seus cimentos e seus pilares fundantes nesse 25 de maio de 2003 quando um homem ao que the haviam dito - como a todos os argentinos - que era impossível construir um país onde houvesse trabalho, bons salários, onde os empresários pudessem ganhar dinheiro e pudéssemos pagar a dívida, ele disse que havia outra maneira de governar, de pensar e que ia leva-la adiante, e deixou a vida nisso de leva-la adiante.. (25/05/2014)

Em segundo lugar, a estabilização de uma narração histórica (e inclusive de uma historiografia) de corte revisionista, que incorpora abertamente o próprio kirchnerismo na saga dos governos populares: ${ }^{33}$

\footnotetext{
${ }^{31}$ Isto já havia sido notado por Retamozo (2013), ainda que não necessariamente em referência a estes atos. O autor explica que, em um primeiro momento, o "kirchnerismo" interpelou um duplo sujeito: a cidadania (populus, os argentinos) em busca de um eleitorado pós-eleitoral, mas ao mesmo tempo fez outra inscrição do povo, a plebs, recuperando uma tradição plebeia do peronismo, interpelando organizações no marco da luta contra setores definidos como dominantes, reacionários, neoliberais e de direita.

${ }^{32}$ A autora concebe as ancoragens narrativas como pontos de referência da "narração", ou seja, da operação de estabilização de significantes no curso de uma disputa política.

${ }^{33}$ Não podemos desenvolver esta ideia aqui, mas é interessante revisar como esta narrativa vai se incorporando à identidade definitiva do kirchnerismo a partir da incorporação, tal como mostram Pérez e Natalucci (2014) das organizações sociais no falido Movimiento Transversal: "Desta forma, o espaço transversal inscrevia a mobilização kirchnerista em um relato que reunia as lutas populares das décadas de 1940, 1970 e 1990 como expressão de um mesmo conjunto de demandas e um sujeito político que reaparece nos momentos críticos da história nacional. Nesta nova etapa, a
} 
EID\&A - Revista Eletrônica de Estudos Integrados em Discurso e Argumentação, Ilhéus, n. 16 esp. "Discurso e argumentação na política latino-americana, set.2018.

Cada ciclo de governos populares teve ataques ferozes, porque na verdade cada uma dessas lideranças não eram eles o problema, mas sim o obstáculo, as ferramentas que a história do povo havia tomado para transformar um destino de escravidão, de atraso. E nós, ele que não está mais, não fomos importantes por nós mesmos, somos apenas uma ferramenta de vocês, o povo, e me refiro não só aos que estão nesta praza. Me refiro a aqueles que sem saber, repetem o que escutam e o que leem. (25 de maio de 2014)

Finalmente, a unção da juventude como herdeira e responsável programática do projeto nacional e popular:

É que não se trata de ir ou ficar, quero que entendam, este é um projeto coletivo, não pode depender de uma só pessoa, depende de vocês para que seja executado, aprofundado e levado adiante. Vocês são o melhor de tudo, os jovens, os milhares de jovens, os milhões de jovens que se incorporaram à atividade política com alegria, com amor, com felicidade. (25/05/2015)

Particularmente, esses três últimos pontos que destacamos mostram, como bem sintetizou Patrouilleau, "um dos potenciais de interpelação do kirchnerismo é também a fonte dos limites expressos na multiplicidade de antagonismos que gera". E esse potencial é "a capacidade discursiva de formular um discurso narrativo que abrange a história do país e que coloca para a atualidade, para suas gestões de governo, como marco fundamental para solucionar a "maldição" social”. Definitivamente, um relato.

Em nosso país, a partir de 2008 e, em particular, uma vez que o kirchnerismo radicalizou seu enfrentamento com o holding Clarín, consagrouse essa expressão -"o relato"- para designar, ao mesmo tempo, um objeto de disputa (ou seja, a construção de uma cosmovisão cultural, que ligasse a releitura da história e os ganhos do Governo) e uma estratégia narrativa mediante a qual o Governo de Cristina teria buscado estilizar narrativamente sua própria gestão. Quando se utiliza isso, ainda hoje, no debate público, quase sem excepções, confere-se a ele uma conotação negativa que o equipara a uma mentira planejada. Entretanto, "o relato" não é, tal como a crítica opositora afirma, um compêndio de mentiras ou enganos, mas sim, o trabalho (que seguindo Pizzorno chamaremos atividade identificante ${ }^{34}$ ) de

Frente se propunha "preencher o vazio de representatividade deixado pela crise dos velhos partidos" (Declaração da Mesa Coordenadora para um Novo Projeto Nacional, junho de 2004)."

34 Pizzorno (1985) explica que a ação política, enquanto funda identidades coletivas, pode se pensar de dois modos: como atividade eficiente e como atividade identificante. Esta última é a tarefa de "construir, preservar, reforçar as identidades coletivas que aparecem sobre a cena pública sob suas múltiplas formas... Tal atividade consiste em produzir símbolos que servem aos membros de uma coletividade dada para reconhecer-se como tais, comunicar sua solidariedade, acordar a ação coletiva". Aí residiria a "peculiaridade" da linguagem dos políticos: "Esta é a trama do que 
EID\&A - Revista Eletrônica de Estudos Integrados em Discurso e Argumentação, Ilhéus, n. 16 esp. "Discurso e argumentação na política latino-americana, set.2018.

alinhavar o diferente, de subsumir as variações, os matizes, inclusive as contradições, em uma narração que concebe o devir histórico como desenvolvimento coerente de um projeto. Como a própria CFK, na ocasião da celebração do ato de 25 de maio de 2012: "foram dois governos mas um só processo".

Por isso, a banalização que a crítica antikirchnerista fez da própria figura do "relato" não deve nos fazer perder de vista sua centralidade na conformação de uma identidade política coletiva. Como perfeitamente o entendeu Verón (1998) em sua reflexão sobre as condições que a midiatização tem (e Verón pensava, particularmente, na televisão) sobre a composição de identidades coletivas: "não se podem construir coletivos identitários de longo prazo unicamente com imagens nem unicamente com a ordem indicial do olhar característico da televisão". Por isso "a construção de uma nova legitimidade do político coloca o problema de uma revalorização do componente linguístico no contexto da televisão".

Como estratégia narrativa, o Relato foi se reproduzindo - com um tema regular, invariante - nestas liturgias, mas não de maneira incidental; pelo contrário, o fez como derivado de um pensamento programático. Foi a própria Cristina que, em seu discurso de assunção como Presidenta, em dezembro de 2007, disse:

Creio também que não só as instituições do Estado em seus três poderes devem abordar a reconstrução de nosso país, creio que também outros níveis da sociedade (empresariais, de liderança, meios de comunicação) devem saber que o fato de não integrar o espaço público governamental, não os exime da tarefa e da responsabilidade que a cada um daqueles argentinos que têm um pouco mais de poder, muito mais poder, eu diria, que o resto dos cidadãos, têm também a obrigação moral de construir um país diferente. Devemo-nos também um relato diferente de nós mesmos os argentinos, não autocomplacência, não de ocultamento, mas sim o necessário reconhecimento dos ganhos obtidos e, em todo caso, a marcar o que falta, mas reconhecer o que se ganhou". ${ }^{35}$

Curiosa a espécie do Relato: se, como ideia, foi anunciada (e, inclusive, rotulada) pela própria Cristina, sua consagração - sua conversão, poderíamos dizer, seguindo Bourdieu, em objeto simbólico - só se produz como um efeito de leitura invertido: primeiro, no discurso dos que, sem dúvida, com

chamamos, especializando um termo da linguagem comum, "discurso político", que obviamente não está formado só por palavras e mensagens, informação, persuasão e ideologia, mas também por modos de relação, por ações exemplares, por emoções sugeridas".

${ }^{35}$ Os itálicos correspondem aos autores. 
EID\&A - Revista Eletrônica de Estudos Integrados em Discurso e Argumentação, Ilhéus, n. 16 esp. "Discurso e argumentação na política latino-americana, set.2018.

sensibilidade premonitória, entenderam que a Presidenta falava sério ${ }^{36}$ e depois, no discurso dos principais dirigentes opositores, que o reduziram a sua forma menos elaborada: a publicidade política em sua variedade genérica de propaganda. Efeito de leitura invertido (o sentido positivo da palavra no discurso de Cristina assume, para os opositores, uma carga negativa), mas, não improvável (porque a própria Cristina habilita uma leitura midiática, como se tudo se tratasse de diferentes maneiras de "construir a realidade"). O Relato, entretanto, estava em outra parte.

Como objeto cultural complexo, irredutível ao discurso presidencial, mas carecido dele para se legitimar, o Relato foi se alinhavando como um dispositivo de interpretação descentralizado - em discursos acadêmicos, jornalísticos, culturais - que articulou um discurso historiográfico posto ao serviço da integração do próprio kirchnerismo na história dos governos nacional-populares na Argentina e da formulação das condições necessárias para sua sobrevivência como projeto político no futuro. Ou seja, uma ferramenta indispensável para a construção de uma identidade coletiva.

\section{Referências}

AMATI, Mirta. Lo que nos dicen los ritos. Democracia y nación en la Argentina del bicentenario. Revista de Ciencias Sociales, n. 18 , p.179-198, 2010.

AUSTIN, John L. Cómo hacer cosas con palabras: Palabras y acciones. Barcelona: Paidós, 1982.

BARREIROS, Raúl. Paisaje del público en la pantalla de televisión. Hoy, lo cómico. Figuraciones, n. 2, v. 3, p.77-92, 2005.

BARREIROS, Raúl; CINGOLANI, Gaston. Lo mediático y el discurso político. El análisis discursivo. Oficios Terrestres, v. XIII, n. 19, p. 102-111, 2007.

BASTIAN TRAMONTINI, Mariana. Operaçoes de sentido na disputa presidencial. Lajeado: WS Editor, 2014.

\footnotetext{
${ }^{36}$ Talvez o primeiro a detectar os indícios foi um dos editores principais do jornal Clarín, Julio Blank, quem escreveu: "O que propõe Cristina, em uso legítimo de seus direitos e atribuições, é uma cruzada para apropriar-se do relato - outra de suas palavras prediletas - da Argentina de hoje. Isso significa admitir, e mais ainda, defender, a ideia de que a realidade e sua percepção se constroem com base em estratégias comunicacionais determinadas, nas quais os fatos comprováveis são apenas um insumo, mas não o produto final" (jornal Clarín, 11/12/2007).
} 
EID\&A - Revista Eletrônica de Estudos Integrados em Discurso e Argumentação, Ilhéus, n. 16 esp. "Discurso e argumentação na política latino-americana, set.2018.

BEN PLOTKIN, Mariano. Rituales políticos, imágenes y carisma: la celebración del 17 de octubre y el imaginario político peronista. In: TORRE, Juan. C. El 17 de octubre de 1945. Buenos Aires: Ariel, 1995.

CARLÓN, Mario. Sobre lo televisivo. Dispositivos, discursos y sujetos. Buenos Aires: La Crujía, 2004.

CHENEY-LIPPOLD, Jonh. A NewAlgorithmic Identity. Soft Biopolitics and the Modulation of Control. Theory, Culture \& Society, v. 28, n.6, p.164-181, 2001.

CINGOLANI, Gastón. A midiatização da figura presidencial: espaços, estratégias e transições. In: FAUSTO NETO, Antoine, MOUCHON, Jean; VERÓN, Eliseo Transformações da midiatização presidencial. Corpos, relatos, negociações, resistências. São Caetano do Sul: Difusão Editora, 2012. p. 53-67.

. La mediatización, entre los cuerpos ciudadanos y el cuerpo presidencial. In: CASTRO, P. C. Dicotomía Público / privado, estamos no caminho certo? Maceió: Edufal, 2015. p. 187-209.

COULOMB-GULLY, Marlène. Napoleão vence Marianne - Representação política e encarnação na campanha presidencial francesa de 2007. In: FAUSTO NETO, Antoine; MOUCHON, A. J.; VERÓN, Eliseo (Org.). Transformações da midiatização presidencial. Corpos, relatos, negociações, resistências. São Caetano do Sul: Difusão Editora, 2012. p. 263-279.

CULIOLI, Antoine. Stabilité et déformabilité en linguistique. In: CULIOLI, Antoine. Pour une linguistique de l'énonciation. Opérations et représentations. Tome 1. Paris: Ophrys, 1990. p.127-134.

DAYAN, Daniel; KATZ, Elihu. La historia en directo. La retransmisión televisiva de los acontecimientos. México DF: Gustavo Gili, 1995.

DEBRAY, Regis. El Estado Seductor. Buenos Aires: Manantial, 2000 [1993].

DUCROT, Oswald; TODOROV, Tzevan. Diccionario enciclopédico de las ciencias del lenguaje. 17 ed. México: Siglo XXI, 1995.

FRANÇA, Vera; GUIMARÃES CORRÊA, Laura. Dilma Rousseff - Transição de imagens no processo de constrção de uma mulher presidenciável. In: FAUSTO NETO, Antoine; MOUCHON, Jean; VERÓN, Eliseo (Org.). Transformações da midiatização presidencial. Corpos, relatos, negociações, resistências. São Caetano do Sul: Difusão Editora, 2012. p. 317-334.

GENETTE, Gérard. Metalepsis. Buenos Aires - México: Fondo de Cultura Económica, 2004.

GINDIN, Irene. La escenografía profesoral como vínculo: el ethos magistral en el discurso de Cristina Fernández de Kirchner (2007-2011). Temas y Debates , n. 33, p.107132, 2017. 
EID\&A - Revista Eletrônica de Estudos Integrados em Discurso e Argumentação, Ilhéus, n. 16 esp. "Discurso e argumentação na política latino-americana, set.2018.

KANTOROWICZ, Ernst. H. Los dos cuerpos del rey. Un estudio de teología política medieval. Madrid: Akal, 2012.

LANDOWSKY, Éric. Eux, nous et moi: régimes de visibilité. Mots, 1985.

LUPTON, D. The quantified self. Malden: Polity Press, 2016.

MAINGUENEAU, Dominique. Ethos, scénographie, incorporation. In: AMOSSY, Ruth. Images de soi dans le discours. La construction de l'ethos. Paris: Delachaux et Niestlé, 1999. p. 75-100.

METZ, Christian. L'énonciation impersonnelle ou le site du film. Paris: Méridiens Klincksieck, 1991.

. El significante imaginario. Barcelona: Gustavo Gilli, 1979.

MONTERO, Ana S. "Y al final un día volvimos". Los usos de la memoria en el discurso kirchnerista (2003-2007). Buenos Aires: Prometeo, 2012.

; VINCENT, Lucia. Del 'peronismo impuro' al 'kirchnerismo puro': la construcción de una nueva identidad política durante la presidencia de Néstor Kirchner en Argentina (2003-2007). POSTData, p.123-157, 2013.

NATALUCCI, Ana. El kirchnerismo y sus estatuto como movimiento político (20032007). Apuntes de Investigación del CECYP, p.133-154, 2012.

; PÉREZ, Germán. El kirchnerismo como problema sociológico. In: NATALUCCI, Ana. Vamos las bandas. Organizaciones y militancia kirchnerista. Buenos Aires: Nueva Trilce, 2014.

NOVARO, Marcos La cultura política y el sentido común bajo el kirchnerismo. In: MALAMUD, Andres. La política en tiempos de Kirchner. Buenos Aires: Eudeba, 2011.

PANKE, Luciana; IASULAITIS, Sylvia. Mulheres no poder: aspectos sobre o discurso feminino nas campanhas eleitorais. Opinião Pública, v.22, n.2, p.385-417, 2016.

PATROUILLEAU, Maria. Discurso y narración en las dinámicas de constitución identitaria. La experiencia kirchnerista en Argentina. Revista Confines, 2010.

PETRIS, José. El protoespacio televisivo: el viejo espectáculo de algunas espontaneidades. In: CINGOLANI, Gáston. Discursividad televisiva. La Plata: Edulp, 2006. p.57-80.

PIZZORNO, Alessandro. Sobre la racionalidad de la opción democrática. In: AA.VV. Los límites de la democracia. Buenos Aires: Clacso, 1985.

RAMíREZ GELBES, Silvia. De Eva a Cristina: Ethos e discurso político. In: FAUSTO NETO, Antônio; MOUCHON, Jean; VERÓN, Eliseo. Transformações da midiatização presidencial. Corpos, relatos, negociações, resistências. São Caetano do Sul: Difusão Editora, 2012. p. 281-299. 
EID\&A - Revista Eletrônica de Estudos Integrados em Discurso e Argumentação, Ilhéus, n. 16 esp. "Discurso e argumentação na política latino-americana, set.2018.

RETAMOzO, Martín. Discursos y lógica política en clave K. In: BALSA, J. Discurso, política y acumulación en el kirchnerismo. Buenos Aires: Unqui-CCC, 2013.

RIVIÈRE, Claude. As liturgias politicas. Rio de Janeiro: Imago, 1989.

. Célébrations et cérémonial de la republique. Hermès, p. 23-29, 2005.

SIGAL, Silvia. La Plaza de Mayo. Una crónica. Buenos Aires: Siglo XXI, 2006.

SOTO, Marita. Silhuetas ou caricaturas? Um olhar sobre o corpo presidencial na imprensa escrita. In: FAUSTO NETO, Antoine; MOUCHON, Jean; VERÓN, Eliseo Transformações da midiatização presidencial. Corpos, relatos, negociações, resistências. São Caetano do Sul: Difusão Editora, 2012. p. 81-89.

TRAVERSA, Oscar. Cuerpos de papel. Figuraciones del cuerpo en la prensa 1918-1940. Barcelona: Gedisa, 1997.

. Los dispositivos del presidente. In: . Inflexiones del discurso. Cambios y rupturas en las trayectorias del sentido. Buenos Aires: Santiago Arcos, 2014. p. 289319.

VALDETTARO, Sandra. Cuerpo-presidencial-performático y Mediatización: entre la sobreexposición y el ocultamiento. In: FAUSTO NETO, Antoine; N. Raimondo Anselmino, \& I. L. GINDIN, Relatos de investigaciones sobre mediatizaciones. Rosario: UNR Editora, 2014, p. 130-156.

VERÓN, Eliseo. La palabra adversativa. Observaciones sobre la enunciación política. In: Hachette, 1987. et al. El discurso político. Lenguajes y acontecimientos. Buenos Aires:

. Corps et méta-corps en démocratie audiovisuelle. Aprèsdemain, n. 293-294, p.32-35, 1987.

. Il est là, je le vois, il me parle. Communications, n. 38, p. 98-120, 1983.

. La semiosis social. Fragmentos de una teoría de la discursividad. Barcelona: Gedisa, 1988.

- Mediatización de lo político. Estrategias, actores y construcción de colectivos. In: MOUCHON, Jean. Comunicación y política. Barcelona: Gedisa, 1998.

. La imagen de una ausencia. In: . Efectos de agenda. Barcelona: Gedisa, 1999. p. 93-96.

- Televisión y democracia. El estatuto de la puesta en escena. In: . El

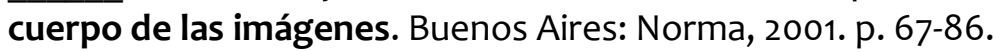

VITALE, María Alejandra. ¿Ethos femenino y feminine style? El primer discurso público de dos presidentes mujeres: Michelle Bachelet (Chile) y Cristina Fernández de Kirchner (Argentina). Lenguaje, v. 44, n. 1,p.61-82, 2016. 
EID\&A - Revista Eletrônica de Estudos Integrados em Discurso e Argumentação, Ilhéus, n. 16 esp. "Discurso e argumentação na política latino-americana, set.2018.

Tradução:

Luciana Carmona Garcia Manzano

Docente do Programa de Pós-Graduação em Linguística da Universidade de Franca (UNIFRAN)

Forma de citação sugerida:

CINGOLANI, Gastón; FERNÁNDEZ, Mariano. O corpo e o coletivo: espetáculo e liturgia midiatizada nos discursos de Cristina Fernández de Kirchner (2008-2015). Trad. Luciana Carmona Garcia Manzano. EID\&A - Revista Eletrônica de Estudos Integrados em Discurso e Argumentação, Ilhéus, n. 16 esp. "Discurso e argumentação na política latino-americana", p. 103-132, set.2018.

Recebido em: 25/07/2018

Aprovado em: 26/08/2018 